\title{
KEJADIAN KAWIN BERULANG PADA SAPI POTONG BETINA PERANAKAN LIMOSIN DAN SIMENTAL DI KECAMATAN WONOSALAM KABUPATEN JOMBANG PERIODE 2015 - 2018
}

\section{THE EVENTS OF REPEAT BREEDING IN LIMOUSIN AND SIMENTAL BREED BEEF CATTLE AT WONOSALAM DISTRICT, JOMBANG PERIOD 2015-2018}

\author{
Muharam Subagio 1), Indah Norma Triana 2), Bambang Poernomo 2), \\ Wurlina 2), Pudji Srianto 2), Budi Utomo 2) \\ 1) Mahasiswa 2) Dosen \\ Fakultas Kedokteran Hewan Universitas Airlangga \\ Kampus C UNAIR, Jl. Mulyorejo-Surabaya 60115 \\ Telp. 031-5992785, Fax. 031-5993015 \\ Email: jbmvunair@gmail.com
}

\begin{abstract}
Repeat Breeding is an adult cattle which have normal estrous cycle and clear signs of estrous but did not get pregnant when it got breed by natural mating or artificial insemination. The main purposes of this study is to know the number of repeat breeding cases in beef cattle in regency Jombang period of 2015-2018. The metode of the study is survey which collected by recording and survey. Were analyzed though Normality Test (Kolmogorov-Smirnov Test) and Homogenity Test and followed by T Test. Questionnaire test result processed using Kendall's Tau$b$ Correlation Test. Study result showed that repeat breeding cases fluctuate significantly per year and the factors affecting fertilization failure and early embrionic death, hormonal, infection, and management factors.
\end{abstract}

Key words: Repeat Breeding, Beef Cattle, Limousin, Simental, Wonosalam, Jombang

\section{PENDAHULUAN}

Hasil Sensus Pertanian 2013 tercatat bahwa populasi sapi dan kerbau pada 1 Mei 2013 mencapai 14,2 juta ekor (BPS, 2013). Hal ini mengalami penurunan yang cukup tajam bila dibandingkan dengan hasil pendataan Sapi Potong, Sapi Perah, dan Kerbau (sensus ternak) yang dilaksanakan Badan Pusat Statistik (BPS) pada Juni 2011. Diketahui, populasi sapi dan kerbau hasil sensus ternak mencapai 16,7 juta ekor. Penurunan populasi pada tahun 2016 mencapai 2,5 juta ekor atau sekitar 15 persen bila dibandingkan dengan kondisi pada 2011. Penyebab penurunan ini salah satunya yaitu menyusutnya populasi sapi potong.
Sapi potong merupakan komoditas ternak yang penting di Indonesia sebagai penghasil daging. Terkait dengan adanya program swasembada daging 2014 yang berarti $90 \%$ pemenuhan kebutuhan daging nasional berasal dari dalam negeri (Kementerian Pertanian, 2010). Produksi komuditas peternakan padatahun 20102014 mengalami pertumuhan yang cukup berarti, yaitu 5,98\% dan populasi sapi potong mengalai peningkatan 13,582 juta ekor pada tahun 2010 dan meningkat pada tahun 2014 sebanyak 14,703 juta ekor (Direktur Jenderal Peternakan dan Kesehatan Hewan, 2013) sedangkan pada tahun 2015 populasi dan produksi sapi potong sebanyak 15,494 juta ekor dan 
kemampuan produksi daging sapi potong tahun 2015 smencapai 523,927 ton (Direktur Jenderal Peternakan dan Kesehatan Hewan, 2015).

Usaha peternakan di Indonesia sampai saat ini masih menghadapi banyak kendala, salah satunya adalah masih banyak kasus gangguan reproduksi menuju kemajiran ternak betina, yang mengakibatkan produktifitas ternak masih rendah. Gangguan reproduksi dapat dipengaruhi oleh beberapa faktor antara lain gangguan keseimbangan hormon reproduksi, pengelolaan kurang baik, penyakit pada alat kelamin khususnya penyakit kelamin menular, kelainan anatomi pada alat kelamin yang bersifat menurun (genetik), kelainan atau patologi pada alat kelamin dan lingkungan yang kurang serasi. (Hariadi dkk., 2011). Rendahnya efisiensi reproduksi pada sapi mengindikasikan terjadinya gangguan reproduksi yaitu kawin berulang (repeat breeding) (Prihatno dkk., 2013).

Kawin Berulang adalah induk hewan yang menmiliki siklus birahi normal dan gejala birahi yang jelas, tetapi bila dikawinkan dengan pejantan yang subur atau diinseminasi buatan dengan sperma berulang-ulang tidak pernah menjadi bunting (Hardjopranjoto, 1995). Kawin berulang pada dasarnya disebabkan oleh faktor genetik, nutrisi, hormonal, infeksi, manajemen, lingkungan dan faktor hewannya (Katagiri, 2004), deteksi estrus (Thatcher dkk., 2006), stress dan hipofungsi korpus luteum. Kegagalan kebuntingan dapat juga disebabkan waktu perkawinan yang kurang tepat seperti yang diungkapakan oleh Noakes dkk. (2009) bahwa perkawinan yang terlalu cepat atau terlambat dapat menyebabkan kegagalan kebuntingan yang ditandai dengan kawin berulang. Saat ini, belum diketahui tingkat kejadian kawin berulang dan faktorfaktor yang memengaruhi kawin berulang pada sapi potong di wilayah kerja Petugas Teknis Kesehatan Wonosalam, Jombang. Kawin berulang merupakan masalah yang penting secara ekonomi pada peternakan sapi. Kerugian ekonomis yang ditimbulkan karena kawin berulang disebabkan meningkatnya biaya untuk perkawinan, calving interval yang panjang, meningkatnya sapi-sapi yang afkir, tidak lahirnya pedet setiap tahun dan biaya operasional. Saat ini, masih belum diketahui tingkat kejadian kawin berulang pada sapi potong peranakan Limousin dan Simental di wilayah kerja Petugas Teknis Kesehatan Wonosalam, Jombang. Oleh karena itu penulis melakukan penelitian untuk mengetahui tingkat kejadian kawin berulang pada sapi potong betina peranakan Limousin dan Simental di wilayah kerja Petugas Teknis Kesehatan Wonosalam, Jombang. Kawin berulang didefinisikan sebagai hewan yang tidak bunting setelah tiga kali inseminasi, meskipun tidak terdeteksi gangguan reproduksi (Yusuf et al., 2010), induk berumur < 10 tahun (Zainudin dkk., 2014) dan bukan dara. Sapi yang mengalami kawin berulang pada umumnya ditandai dengan adanya calving interval (18-24 bulan), rendahnya angka konsepsi $(<40 \%)$, dan tingginya service perconception (>3) (Rustamaji et al.,2007).

Siklus birahi pada sapi dibagi menjadi empat periode menurut perubahan- perubahan yang tampak maupun yang tidak tampak dari luar selama siklus birahi yaitu proestrus, estrus, metestrus dan diestrus. Keempat periode tersebut yang dapat diamati oleh peternak adalah periode estrus karena terdapat gejala fisik yang jelas tampak dari luar dan dalam bahasa jawa dikenal dengan 3A (Abang, Abuh, Anget), yang dapat disimpulkan dari kata "anget" atau hangat tersebut adalah meningkatnya suhu vulva dari sapi potong yang mengalami birahi (Ismudiono dkk., 2010). Selama estrus, sapi betina menjadi sangat tidak tenang, kurang nafsu makan, dan kadang- 
kadang menaiki sapi-sapi betina lain dan akan diam berdiri bila dinaiki. Vulva ternak tersebut akan membengkak, memerah dan penuh dengan sekresi mucus transparan yang menggantung dari vulva atau terlihat di pangkal ekor (Achyadi, 2009).

Salah satu penyebab kawin berulang adalah kuantitas atau kualitas nutrisi yang tidak tercukupi (Fahey,2002). Hubungan antara reproduksi dengan status nutrisi pada sapi sangat erat kaitannya (Wettemann, 2003). Kekurangan nutrisi merupakan faktor utama yang menghambat sistem reproduksi sapi di daerah-daerah tropis. Nutrisi yang tidak tercukupi dalam hal kualitas maupun kuantitas dapat berpengaruh langsung terhadap efisiensi reproduksi, seperti rendahnya kinerja reproduksi dan produktivitas. Defisiensi nutrisi juga salah satu penyebab aktivitas ovarium menjadi tidak optimal dan terjadi gangguan hormon, sertabody score yang rendah, menyebabkan calving interval panjang, yang pada akhirnya menyebabkan kawin berulang (Salem, 2006). Faktor kesalahan manajemen dapat menyebabkan kegagalan kebuntingan yang ditandai dengan adanya gejala kawin berulang (Windig, 2005). Kegagalan dalam mendeteksi estrus merupakan salah satu faktor yang dapat menyebabkan problem reproduksi dan rendahnya angka kebuntingan pada kelompok ternak sapi perah (Thatcher, 2006).

Kecamatan Wonosalam merupakan wilayah tempat usaha pengembangan ternak sapi potong Limousin dan Simental. Pengembangan yang dilakukan oleh Dinas Peternakan Kabupaten Jombang, peternakan pada daerah ini mengawinkan ternak sapi dengan cara Inseminasi Buatan. Inseminasi Buatan merupakan salah satu bentuk program yang dilakukan oleh Dinas Peternakan Kabupaten Jombang dalam rangka peningkatan produksi sapi potong di Kecamatan
Wonosalam (Dinas Kabupaten Jombang, 2018).

\section{MATERI DAN METODE PENELITIAN}

\section{Materi Penelitian}

Materi yang digunakan dalam penelitian ini adalah data sapi betina persilangan Limousin dan Simental yang mengalami kasus kawin berulang dari catatan petugas kesehatan hewan/inseminator. Data peternak yang diambil meliputi jumlah sapi yang mengalami kawin berulang sebagai variabel bebas.

\section{Metode Penelitian}

Metode penelitian yang digunakan adalah metode survey dengan teknik pengambilan data menggunakan data recording yang dimiliki Inseminator dan pemberian kuisioner kepada peternak, sehingga sapi betina yang mempunyai kasus kawin berulang digunakan sebagai sampel. Data yang digunakan adalah data sekunder. Variabel bebas dalam penelitian ini adalah sapi peranakan Limousin dan Simental. Variabel tergantung yang diamati adalah kawin berulang pada sapi betina peranakan Limousin dan Simental. Variabel kontrol pada penelitian ini adalah cara pemeliharaan yang dilakukan oleh peternak, pakan yang diberikan serta kondisi kandang tempat pemeliharaan. Definisi operasional variabel dari penelitian ini, yaitu kawin berulang atau sudah dilakukan inseminasi buatan lebih dari tiga kali namun tidak terjadi kebuntingan. Data yang telah diperoleh dari recording milik inseminator untuk jumlah kawin berulang dan pemberian kuisioner terhadap peternak yang terdapat di di wilayah kerja Petugas Teknis Kesehatan Hewan Kecamatan Wonosalam Kabupaten Jombang, selanjutnya data sapi betina yang mengalami kawin 
berulang dikelompokkan berdasarkan variabel independen. Data yang telah terkumpul dianalisis menggunakan Uji Normalitas (Kolmogorov-Smirnov Test) dan Uji Homogenitas untuk menilai kelayakan data yang akan diproses. Kemudian dilanjutkan dengan uji T Test untuk mengetahui adanya perbedaan yang signifikan. Untuk data kuisioner diolah menggunakan uji Korelasi Kendall's Tau-b utuk melihat ada atau tidaknya korelasi dan besar korelasi pada faktor-faktor yang dapat mempengaruhi variabel. Data dianalisa menggunakan software SPSS.

\section{HASIL}

Jumlah sapi potong betina di Kecamatan Wonosalam, Kabupaten Jombangpada tahun 2015 - 2018 sebesar 3098 ekor (peranakan simental 1240 ekor dan 1858 ekor peranakan limosin), 3441 ekor (peranakan simental 1377 ekor dan 2064 ekor peranakan limosin), 3556 (peranakan simental 1411 ekor dan 2115 ekor peranakan limosin) dan 3660 (peranakan simental 1501 ekor dan 2159 ekor peranakan limosin) yang diperoleh dari data petugas keswan dan IB (Gambar 4.1, Tabel 4.1). Sedangkan hasil rekapitulasi jumlah populasi yang didiagnosa kawin berulang pada tahun 2015 terdiri dari 341 ekor peranakan sapi simental dan 243 ekor peranakan limosin, tahun 2016 terdiri dari 352 ekor peranakan sapi simental dan 231 ekor peranakan limosin, tahun 2017 terdiri dari 455 ekor peranakan sapi simental dan 341 ekor peranakan limosin, tahun 2018 terdiri dari 441 ekor peranakan sapi simental dan 332 ekor peranakan limosin (Gambar 4.1, Tabel 4.2). Data dalam penelitian ini data populasi Sapi Peranakan Simental dan Populasi Sapi Peranakan Limosin dianalisis menggunakan Uji $\mathrm{T}$ untuk menunjukkan perbedaan antara populasi sapi Peranakan Simental dan limosin, namun sebelum data diproses harus dilakukan syarat-syarat uji yaitu
Uji Normalitas (Kolmogorov-Smirnov Test) dan Uji Homogenitas untuk menilai kelayakan data yang akan diproses. Hasil Uji Normalitas menunjukan angka 0,905 yang dapat diartikan data terdistribusi dengan normal $(p>0,05)$. Hasil Uji Homogeitas menunjukan angka 0,082 yang dapat diartikan data yang diambil homogen $(p>0,05)$ (Tabel 4.1).

Deskripsi data yang terdapat pada Uji-T menunjukkan populasi Sapi Peranakan Simental sebesar 397,25 \pm 59,0 sedangkan populasi Sapi Peranakan Limosin sebesar $286,75 \pm 28,8$. Hasil Uji$\mathrm{T}$ Sig. (2-tailed) menunjukkan angka 0,037 yang bermakna terdapat perbedaan yang nyata antara populasi Sapi Peranakan Simental dan Limosin. Mean Difference menghasilkan angka sebesar 110,5 yang bermakna rerata kelompok kedua yakni Populasi Sapi Peranakan Limosin lebih tinggi dari kelompok pertama yakni Populasi Sapi Peranakan Simental (Tabel 4.1).

Data dari pembagian kuisioner kepada peternak yang terdiri dari Pengetahuan Siklus, Pengetahuan Tanda Estrus, Pengamatan Estrus, jarak Pelaporan dengan waktu IB, Pakan yang diberikan, Body Condition Score, Service per Conception dan Beranak berapa kali diolah menggunakan Uji Korelasi Kendall's Tau-b utuk melihat ada atau tidaknya korelasi dan besar korelasi pada faktor-faktor yang dapat mempengaruhi kejadian Kawin Berulang di Kecamatan Wonosalam Kabupaten Jombang.

Hasil Uji normalitas didapatkan Sig. (2-tailed) sebesar 0,000 pada seluruh faktor, oleh karena itu dilanjutkan dengan uji korelasi nonparametrik Kendall's Tau-b yang menunjukkan beberapa faktor saling berkaitan atau signifikan $(p<0,05)$ dalam kejadian Kawin Berulang. Pakan - Body Condition Score memiliki nilai koefisiensi korelasi positif sebesar 0,807 (hubungan yang sangat kuat). Pakan Pengetahuan Tanda Estrus memiliki 
nilai koefisiensi korelasi positif sebesar 0,547 (Hubungan yang kuat). Pengamatan Estrus - Pengetahuan Siklus memiliki nilai koefisiensi korelasi positif sebesar 0,486 (Hubungan yang cukup). Body Condition Score Pengetahuan Tanda Estrus memiliki nilai koefisiensi korelasi positif sebesar 0,422 (Hubungan yang cukup).

\begin{tabular}{|c|c|c|c|}
\hline Tahun & Simental & Limosin & Populasi Total \\
\hline 2015 & 1240 & 1858 & 3098 \\
\hline 2016 & 1377 & 2064 & 3441 \\
\hline 2017 & 1411 & 2115 & 3556 \\
\hline 2018 & 1501 & 2159 & 3660 \\
\hline
\end{tabular}

Tabel .1 Data Populasi Sapi Potong Betina Peranakan Simental dan Limosin di Kecamatan Wonosalam, Kabupaten Jombang Pada Tahun 2015-2018

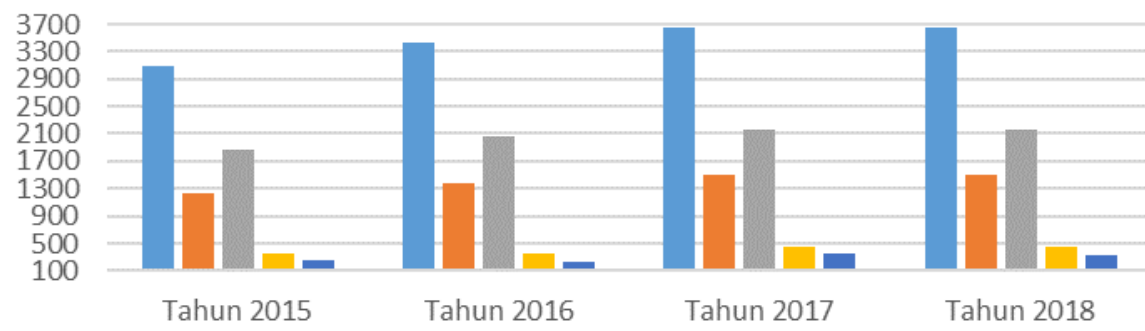
- Populasi Sapi Potong Betina
- Peranakan Simental
Peranakan Limosin
Kawin Berulang (Peranakan Simental)
- Kawin Berulang (Peranakan Limosin)

Gambar 1 Data populasi, Peranakan Simental dan Limosin dan kejadian Kawin Berulang

\begin{tabular}{|c|c|c|c|c|c|c|}
\hline Tahun & \multicolumn{2}{|c|}{ Simental } & \multicolumn{2}{c|}{ Limosin } & \multicolumn{2}{c|}{ Jumlah Kasus } \\
\hline 2015 & 341 & $27.50 \%$ & 243 & $13.07 \%$ & 584 & $18.85 \%$ \\
\hline 2016 & 352 & $25.56 \%$ & 231 & $11.19 \%$ & 583 & $16.94 \%$ \\
\hline 2017 & 455 & $32.24 \%$ & 341 & $16.12 \%$ & 796 & $22.38 \%$ \\
\hline 2018 & 441 & $29.38 \%$ & 332 & $15.37 \%$ & 773 & $21.12 \%$ \\
\hline
\end{tabular}

Tabel 2 Jumlah Kasus Kawin Berulang Pada Sapi Potong Betina Peranakan Simental dan Limosin di Kecamatan Wonosalam, Kabupaten Jombang Pada Tahun 2015-2018 
Tabel 3. Hasil Uji-T

\begin{tabular}{|l|c|}
\hline \multicolumn{1}{|c|}{ Uji T } \\
\hline $\begin{array}{l}\text { Populasi Sapi Potong } \\
\text { Peranakan Simental * }\end{array}$ & Sig. (2-tailed)0,037 \\
$\begin{array}{l}\text { Populasi Sapi Potong } \\
\text { Peranakan Limosin }\end{array}$ & Mean Difference \\
\hline
\end{tabular}

\section{PEMBAHASAN}

Dari hasil yang telah didapatkan diketahui bahwa terdapat perbedaan yang nyata antara populasi Sapi Peranakan Simental dan Limosin. Mean Difference menghasilkan angka sebesar 110,5 yang bermakna rerata kelompok pertama yakni Populasi Sapi Peranakan Simental lebih tinggi dari kelompok kedua yakni Populasi Sapi Peranakan Limosin (Tabel 1). Populasi sapi peranakan limosin di Kecamatan Wonosalam, Kabupaten Jombang lebih tinggi daripada sapi peranakan simental yang mungkin dikarenakan masyarakat sekitar lebih menyukai sapi pernakan limosin. Ada kemungkinan bahwa perawakan, berat badan, dan hal lainnya menyebabkan masyarakat di Kecamatan Wonosalam, Kabupaten Jombang lebih memilih untuk memelihara sapi peranakan limosin daripada sapi peranakan simental. Namun, jumlah kejadian kawin berulang di Kecamatan Wonosalam lebih banyak terjadi pada sapi peranakan simental yang populasinya justru lebih sedikit daripada sapi peranakan limosin (Tabel 1). Kawin berulang merupakan suatu keadaan sapi betina yang tidak mengalami kebuntingan setelah dikawinkan sebanyak tiga kali atau lebih menggunakan inseminasi buatan (Amiridis dkk., 2009).
Terjadinya kawin berulang dapat diindikasikan oleh rendahnya efisiensi reproduksi pada sapi (Prihatno dkk., 2013). Kejadian kawin berulang mungkin dapat terjadi karena beberapa faktor yang dapat dilihat dari hasil kuisioner yang didapat seperti : faktor pakan - Body Condition Score memiliki nilai koefisiensi korelasi positif sebesar 0,807 (hubungan yang sangat kuat), Pakan - Pengetahuan Tanda Estrus memiliki nilai koefisiensi korelasi positif sebesar 0,547 (Hubungan yang kuat), Pengamatan Estrus - Pengetahuan Siklus memiliki nilai koefisiensi korelasi positif sebesar 0,486 (Hubungan yang cukup), Body Condition Score Pengetahuan Tanda Estrus memiliki nilai koefisiensi korelasi positif sebesar 0,422 (Hubungan yang cukup) (Tabel 2). Faktor-faktor diatas dapat digunakan sebagai acuan untuk mengetahui penyebab kejadian kawin berulang yang terjadi di Kecamatan Wonosalam, Kabupaten Jombang seperti penyebab-penyebab utama kejadian kawin berulang yang selama ini telah kita ketahui seperti : kegagalan fertilisasi dan kematian embrio dini (Hardjopranjoto, 1995); gangguan hormonal, lingkungan, nutrisi, dan manajemen (Toelihere, 1993); dan faktor genetik, infeksi, gangguan ovarium, gangguan reproduksi seperti distokia, retensi plasenta, dan prolaps uterus (Hardjopranjoto, 1995). 
Dari hasil kuisioner dapat diketahui bahwa faktor yang memiliki korelasi yang kuat terhadap kejadian kawin berulang di Kecamatan Wonosalam adalah faktor Pakan - Body Conditioning Score serta faktor Pengetahuan tanda estrus. Pakan merupakan hal yang sangat penting dalam peternakan sapi dimana pakan merupakan hal yang harus diperhatikan terutama pada bahan pakan, formulasi ransum dan cara pemberiannya (Nurhadi, 2010). Pakan juga merupakan salah satu faktor utama yang akan mempengaruhi kesehatan tubuh maupun kesehatan reproduksi ternak (Sudono dkk., 2004). Kebutuhan nutrisi yang seimbang sangat penting untuk kesehatan reproduksi sapi. Defisiensi dari mineral dapat menyebabkan penundaan pubertas dan tanda-tanda birahi yang tidak normal (Yendraliza, 2013) serta berpengaruh terhadap kawin berulang, aktivitas ovarium, dan rendahnya efisiensi reproduksi (Winugroho, 2002). Selain itu menurut Winugroho (2002) defisiensi nutrisi akan menyebabkan late estrus, silent heat, hingga anestrus. Kekurangan protein dapat menyebabkan timbulnya birahi yang lemah, birahi tenang, anestrus, kawin berulang, kematian embrio dini, absorbsi embrio yang mati oleh dinding uterus, hingga kelahiran anak

Kejadian kawin berulang di Kecamatan Wonosalam, Kabupaten Jombang memperlihatkan bahwa angka kejadian kawin berulang lebih banyak terjadi pada sapi peranakan simental daripada sapi peranakan limosin. Hal ini dapat disebabkan oleh berbagai faktor. Salah satu faktor yang mungkin mempengaruhi adalah faktor genetik. Fisiologi reproduksi melibatkan beberapa proses parakrin; autokrin; dan endokrin yang diatur secara ketat oleh sejumlah besar gen, dan inkompatibilitas pada salah satu jalur tersebut dapat mengakibatkan infertilitas (Venkatesh dkk., 2014). Sapi peranakan simental yang keturunannya sudah bercampur dengan sapi jenis lain mungkin dapat mengakibatkan terjadinya mutasi genetik yang mungkin menyebabkan sistem imun ataupun sistem reproduksi terdeteriosasi sehingga kawin berulang terjadi lebih sering. Selain itu faktor nutrisi dapat berpengaruh juga apabila pemberian pakan peternak berbeda baik dalam hal jenis ataupun jumlah pemberian. Hal ini mungkin disebabkan oleh kesenjangan ekonomi antar peternak sehingga terdapat perbedaan dalam pemberian pakan terhadap ternak menjadi tidak seimbang. Faktor inseminator yang berbeda tiap daerah antar kecamatan juga dapat mempengaruhi karena kualitas inseminator pastinya tidak sama. Ketidaklengkapan data pada tahun 2015-2016 dimana program Sapi Indukan Wajib Bunting (SIWAB) belum terjalankan dapat dikaitkan dengan jumlah pelaporan kejadian kawin berulang yang meningkat secara signifikan pada tahun 2017 karena pada program SIWAB data telah terintegrasi secara digital dari bawah hingga pusat sehingga ketersediaan data lebih baik.

\section{KESIMPULAN}

Kejadian kawin berulang di Kecamatan Wonosalam, Kabupaten Jombang mengalami fluktuasi yang signifikan dari tahun 2015-2018. Tahun 2016 mengalami penurunan, tahun 2017 mengalami peningkatan dari tahun 2016, dan tahun 2018 mengalami penurunan dari tahun sebelumnya.

Ada beberapa faktor yang mungkin menyebabkan terjadinya kawin berulang seperti kegagalan fertilisasi dan kematian embrio dini, hormonal, infeksi serta faktor manajemen.

\section{SARAN}

Pemerintah daerah perlu mengadakan sosialisasi ke peternak mengenai siklus reproduksi, tanda 
estrus serta gangguan reproduksi pada sapi potong agar kejadian kawin berulang dapat ditekan

Pemerintah daerah perlu memberikan dukungan ke peternak baik dalam hal manajemen, pakan, maupun pengobatan agar kesejahteraan peternak meningkat serta menekan jumlah kejadian kawin berulang seperti kegagalan ferilisasi dan kematian embrio dini.

\section{DAFTAR PUSTAKA}

Achyadi K. R., 2009. Deteksi Berahi pada Ternak Sapi. Tesis MS Pascasarjana IPB. Bogor.

Amiridis G.S., T.H. Tsiligianni, E. Dovolou, C. Rekkas, D. Vouzaras, and I. Menegatos. 2009. Combined administration of gonadotropinreleasing hormone, progesterone, and meloxicam is an effective treatment for the repeat-breeder cow. Theriogenology 72:542-548.

Direktur Jenderal Peternakan dan Kesehatan Hewan. 2013. Buku Statistik Peternakan dan Kesehatan Hewan Tahun 2013. Kementerian Pertanian.

Direktur Jenderal Peternakan dan Kesehatan Hewan. 2015. Buku Statistik Peternakan dan Kesehatan Hewan Tahun 2015. Kementerian Pertanian.

Fahey, J., K. O'Sullivan, J. Crilly, and J.F. Mee. 2002. The effect of feeding and management practices on calving rate in dairy herds. Anim. Reprod. Sci. 74:133-150.

Hariadi, M., S. Hardjopranjoto., Wurlina., H.A. Hermadi., B. Utomo., Rimayanti., I.N. Triana dan H. Ratnani. 2011. Ilmu Kemajiran pada Ternak Cetakan
1. Airlangga University Press. Surabaya.

Hardjopanjoto, H. S. 1995. Ilmu Kemajiran Pada Ternak. Airlangga University Press. Surabaya

Ismudiono, P. Srianto, H. Anwar, S. P. Madyawati, A. Samik, dan E. Safitri. 2010. Buku Ajar Fisiologi Reproduksi pada Ternak. Departemen Reproduksi Veteriner. Fakultas Kedokteran Hewan Universitas Airlangga.

Katagiri S. and Y. Takahashi. 2004. Changes in EGF Concentrations During Estrous Cycle in Bovine Endometrium and Their Alterations in Repeat Breeder Cows. Theriogenology 62: 103-112.

Kementerian Pertanian Republik Indonesia. 2015. Peraturan Menteri Pertanian Republik Indonesia Noor 46/Permentan/PK.210/8/2015

Noakes, D.E., T. Parkinson, G.C.W. England, G.H. Arthur. 2009. Arthur's Veterinary Reproduction and Obstetrics, ninth ed. Elsevier Sci. Ltd, 399408

Nurhadi, M. 2010. Dimensi Sosiologis Dalam Upaya Meningkatkan Kualitas Susu Sapi Perah. Sosiologi Fisip Universitas Sebelas Maret Surakarta

Prihatno S. A., A. Kusumawati, N. W. K. Karja dan B. Sumiarto. 2013. Prevalensi dan Faktor Resiko Kawin Berulang pada Sapi Perah pada Tingkat Peternak. Jurnal Veteriner Vol. 14 No. 4:452-461. 
Rustamadji. B, Ahmadi, Kustono, dan T. Sutarno. 2007. Kinerja Usaha Peternakan Sapi Perah Rakyat Sebagai Tulang Punggung Pembangunan Persusuan Nasional. Paper. Disampaikan pada Lokakarya Persusuan Nasional. Yogyakarta. Dies 38 Fapet UGM.

Safitri, T. 2011. Penerapan Good Breeding Practices Sapi Potong di PT Lembu Jantan Perkasa Serang Banten. Skripsi. Fakultas Peternakan Institut Pertanian Bogor. Bogor.

Salem, M.B., M. Djemali, C. Kayouli, and A. Majdoub. 2006. A review of environmental and management factors affecting the reproductive performance of Holstein-Friesian dairy herds in Tunisia. Livestock Research for Rural Developm. 18(4):123-129.

Sudono, A., R.F. Rosdiana dan B.S. Setiawan. 2004. Beternak Sapi Perah Secara Intensif. Agromedia Pustaka. Jakarta

Thatcher W. W., T. R. Bilby, J. A. Bartolome, F. Silvestre, C. R. Staples, J. E. P Santos. 2006. Strategies for Improving Fertility in Themodern Dairy Cow. Theriogenology 65: 30-44

Toelihere, M. R. 1993. Inseminasi Buatan Pada Ternak. Angkasa. Bandung

Venkatesh, T., P.S. Suresh dan R. Tsutsumi. 2014. New Insight into The Genetic Basic of Infertility. Appl Clin Genet. 2014; 7: 235-243
Wettermann, R.P., C.A. Lents, N.H. Ciccioli, F.J. White, and I. Rubio. 2003. Nutritional and sucklingmediated anovulation in beef cows. J. Anim. Sci. 81 (E. Suppl. 2): E48-E59.

Windig J.J., M.P. Calus, and R.F. Veerkamp. 2005. Influence of herd environment on health and fertility and their relationship with milk production. J Dairy Sci 88:335-47.

Winugroho, M. 2002. Strategi Pemberian Pakan Tambahan Untuk Memperbaiki Efisiensi Reproduksi Induk Sapi. Balai Penelitian Ternak. Jurnal Litbang Pertanian 21(1): 19-23

Yendraliza. 2013. Pengaruh Nutrisi Dalam Pengelolaan Reproduksi Ternak (Studi Literatur). Jurnal Penelitian Sosial Keagamaan, Vol 16, No.1 Januari-Juni 2013.

Yusuf M, T. Nakao, B.M.K. Ranasinghe, G. Gautam, S.T. Long, C. Yoshida, K. Koike dan A. Hayashi. 2010. Reproductive performance of repeat breeders in dairy herds. Theriogenology. 73: 1220-1229.

Zainudin M., M. Nur Ihsan dan Suyadi. 2014. Efisiensi Reproduksi Sapi Perah PFH pada Berbagai Umur di CV. Milkindo Berka Abadi Desa Tegalsari Kecamatan Kepanjen Kabupaten Malang. Jurnal Ilmu-Ilmu Peternakan 24 (3):32-37 